\title{
Turnover and Metabolism of Catecholamines in Patients with Pheochromocytoma *
}

\author{
J. Richard Crout $\dagger$ and Albert Sjoerdsma \\ (From the Experimental Therapeutics Branch, National Heart Institute, Bethesda, Md.)
}

When norepinephrine (NE) or epinephrine (E) is infused into a human subject, all but about $4 \%$ of the amine is metabolized to urinary O-methylated and deaminated metabolites (1-4). The percentage excreted as each metabolite is fairly constant even in different individuals (1-3). This is in distinct contrast to the situation in patients with pheochromocytoma. In this disease patients with similar excretion values for free catecholamines may show up to tenfold differences in their excretion rates of metabolites (5). This implies that a pheochromocytoma may not be simply an endogenous source of circulating $\mathrm{NE}$ and $\mathrm{E}$; catecholamine metabolism in these patients is more complex than traditional views would suggest.

This paper describes $a$ ) the urinary excretion rates of $\mathrm{NE}$ and $\mathrm{E}$ and of their two major metabolites in 24 patients with pheochromocytoma, $b$ ) the NE and E content of the tumors of 23 of these patients, and $c$ ) the normetanephrine $(\mathrm{NMN})$ plus metanephrine $(\mathrm{MN})$ content of 9 tumors. An analysis of these data reveals certain correlations, not previously emphasized, between the size of the tumor, the rate of turnover of catecholamines within the tumor, and the pattern of catecholamine metabolites in the urine. We concluded that in some pheochromocytomas much of the catecholamine synthesized is degraded directly in the tumor before it ever reaches the circulation. This process may partially "protect" the patient from the cardiovascular effects of his tumor and thereby modify the clinical course of the disease.

\section{Materials and Methods}

Two of the 24 patients studied had malignant disease with widespread metastases; each of the others had a

* Submitted for publication June 7, 1963 ; accepted September 26, 1963.

$\dagger$ Present address: Department of Pharmacology, University of Texas Southwestern Medical School, Dallas, Texas. single tumor. Most patients had sustained or fluctuating hypertension, but one (No. 17) had hypertension only during paroxysmal attacks.

Twenty-four hour urine specimens were collected in glass bottles containing 10 to $15 \mathrm{ml} 6 \mathrm{~N}$ hydrochloric acid and were stored at $-20^{\circ} \mathrm{C}$ or at $0^{\circ} \mathrm{C}$. Portions of tumor were frozen on removal and stored at $-20^{\circ} \mathrm{C}$ until the time of assay. Urine specimens and tumor samples shipped from outside hospitals were kept frozen on dry ice en route. Free urinary $\mathrm{NE}$ and $\mathrm{E}$ were determined fluorimetrically by a modification of the trihydroxyindole method (6). The mean recovery of $\mathrm{NE}$ plus $\mathrm{E}$ was $87 \%$; the results were not corrected for this small loss. Total NMN plus MN was determined by a modification of Pisano's method (5); no correction was made for an average recovery of $84 \%$. This method measures the combined total of free and conjugated NMN plus MN but does not distinguish between these two O-methylated amines. Urinary 3-methoxy-4-hydroxymandelic acid (vanilmandelic acid, VMA) was measured by the method of Pisano, Crout, and Abraham (7); the recovery in this procedure is quantitative.

Tumors were assayed for $\mathrm{NE}$ and $\mathrm{E}$ by homogenizing 0.5 to $1.0 \mathrm{~g}$ of tissue in $10 \mathrm{ml}$ cold $5 \%$ trichloroacetic acid, centrifuging to obtain a clear supernatant solution, and assaying this extract fluorimetrically. The tumor content of NMN plus $\mathrm{MN}$ was determined by preparing a 5\% trichloroacetic acid extract as described above, adjusting its $\mathrm{pH}$ to 8.4 with $2 \mathrm{~N}$ ammonium hydroxide, and passing it over a $1.2-\times 6-\mathrm{cm}$ column of alumina to remove catecholamines. The effluent was then brought to $\mathrm{pH} 6.0$ with $1 \mathrm{~N}$ acetic acid and carried through the procedure for total NMN plus $\mathrm{MN}$ in the same manner as for hydrolyzed urine specimens. Tissue samples were taken from central portions of the tumor; areas of fibrosis and necrosis were avoided.

Calculations were made in the following manner. The mean daily excretion values for free $\mathrm{NE}$ and $\mathrm{E}$, NMN plus $M N$, and VMA for patients without tumors (5) (designated "normal" in Table I) were subtracted from the corresponding values in each patient. The sum of these corrected values was considered equal to the total daily catecholamine production of the patient's tumor. Since these compounds actually account for only 60 to $85 \%$ of the metabolites excreted in the urine after an iv infusion of radioactive $\mathrm{NE}$ or $\mathrm{E}$ in man (1-3), these calculated values for "total catecholamine production" are probably low by a factor that is assumed to be constant for all patients. The total NE plus $\mathrm{E}$ content of the tumor was assumed to be equal to the catecholamine 
content of the portion analyzed (milligrams per gram) times the weight of the tumor. The rate of turnover of catecholamines in the tumor was expressed as "per cent of NE plus $\mathrm{E}$ in the tumor released per day"; if steadystate conditions are assumed, this rate is equal to:

$\frac{\text { total daily catecholamine production }(\mathrm{mg} \text { per day) }}{\text { total } \mathrm{NE}+\mathrm{E} \text { content of tumor }(\mathrm{mg})} \times 100$.

\section{Results}

Most of the data obtained in this study are summarized in Table I. The urinary excretion rates shown are derived from assays of single 24-hour urine specimens collected when the clinical condition of the patient was considered stable. The values given are believed to approximate the average excretion rates of each compound, since urinary assays in 8 patients (No. 1, 2, 5, 8, 10, 11, 20 , and 23 ) on 2 to 8 separate days showed that individual values for any one day differed from the mean of all days by no more than $20 \%$.

Excretion of catecholamines and metabolites. In Figure 1 the excretions of free catecholamines and of total metabolites in Patients 1 to 22 are plotted as functions of the total amount of NE plus $\mathrm{E}$ in the tumors; for convenience a logarithmic scale is used along the abscissa. Although there is considerable variation, it is apparent that the free catecholamine excretion (Figure 1B) was frequently high in patients with small amounts of $\mathrm{NE}$ plus $\mathrm{E}$ (less than $100 \mathrm{mg}$ ) in their tumors. With the exception of Patient 22, the free catecholamine excretion in patients with large tumor stores of catecholamines was relatively low. Total catecholamine production (Figure 1A) was very high in 3 patients who had large amounts of catecholamine in their tumors (No. 18, 21, and 22 ), but in the remaining patients the excretion of total urinary metabolites was not clearly related to the size of the catecholamine pool in the tumor.

Turnover rates of catecholamines in tumors. The rates of release of catecholamines from the tumors of these patients varied from 1.4 to $220 \%$ per day. As shown in Figure 2A, the fraction of the tumor pool of $\mathrm{NE}$ plus $\mathrm{E}$ released per day decreased as the tumor content of catecholamines increased. This decline in turnover rate with increasing pool size was accompanied by a decrease in the percentage of the total urinary metabolites present as free catecholamines (Figure 2B). In other words, $\mathrm{NE}$ and $\mathrm{E}$ were apparently metabolized more completely in those patients who had a large tumor pool and a low rate of turnover of catecholamines.

Figures 1 and 2 clearly demonstrate that the parameters shown are not related linearly; this

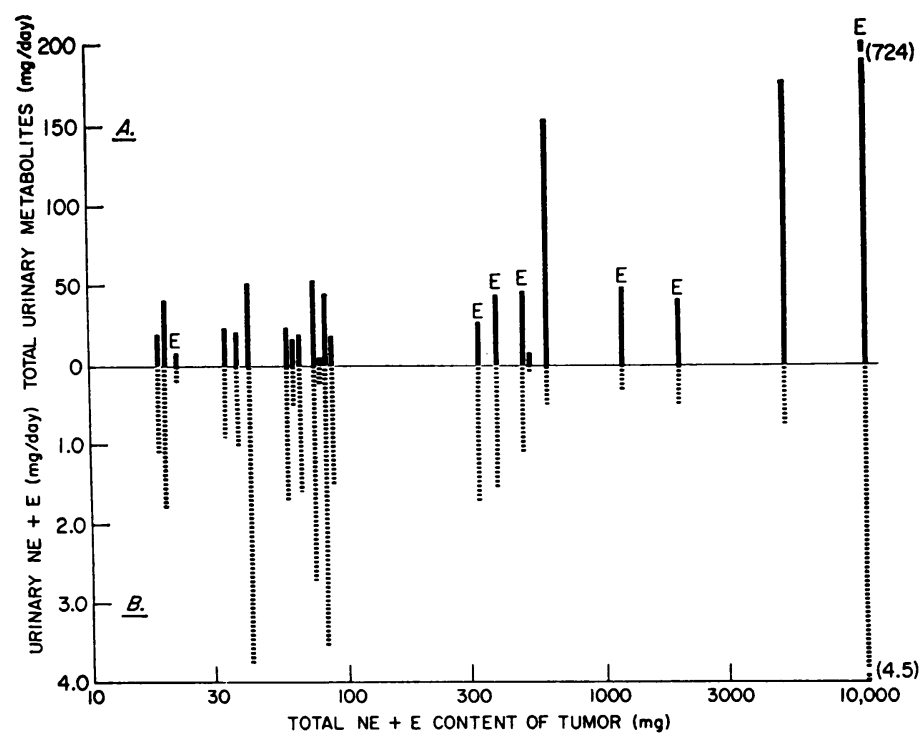

Fig. 1. Total catecholamine production (1A) and free NE plus E (1B) in 22 patients with pheochromocytoma plotted as FUNCTIONS OF THE TOTAL CONTENT OF NE PLUS E OF THEIR TUMORS. $\mathrm{E}=$ tumor that produced an increase in urinary $\mathrm{E}$ as well as $\mathrm{NE}$. 
TABLE I

Summary of pertinent

\begin{tabular}{|c|c|c|c|c|c|c|c|c|c|c|}
\hline \multirow[b]{2}{*}{$\begin{array}{c}\text { Case } \\
\text { no. }\end{array}$} & \multirow[b]{2}{*}{ Age } & \multirow[b]{2}{*}{ Sex } & \multicolumn{8}{|c|}{ Urinary excretion of catecholamines and metabolites $\dagger$} \\
\hline & & & NE & $\mathrm{E} \ddagger$ & $\mathrm{NMN}+\mathrm{MN}$ & VMA & Total & $\mathrm{NE}+\mathrm{E}$ & $\begin{array}{l}\mathrm{NMN} \\
+\mathrm{MN}\end{array}$ & VMA \\
\hline & & & $m g / d a y$ & $m g / d a y$ & $m g / d a y$ & $m g / d a y$ & $m g / d a y$ & \multicolumn{3}{|c|}{$\%$ of total } \\
\hline 1 & 40 & M & 1.04 & ND & 4.0 & 15 & 20 & 5.2 & 20 & 75 \\
\hline 2 & 12 & M & 1.78 & ND & 10.5 & 32 & 44 & 4.0 & 24 & 73 \\
\hline 3 & 65 & $\mathrm{~F}$ & 0.105 & 0.051 & 1.0 & 8.3 & 9.5 & 1.6 & 11 & 87 \\
\hline 4 & 4 & $\mathrm{M}$ & 0.90 & ND & 6.0 & 18 & 25 & 3.6 & 24 & 72 \\
\hline 5 & 12 & M & 1.00 & ND & 4.9 & 15 & 21 & 4.8 & 23 & 72 \\
\hline 6 & 29 & M & 3.80 & ND & 15 & 36 & 55 & 6.8 & 27 & 65 \\
\hline 7 & 24 & $\mathrm{~F}$ & 1.66 & ND & 5.4 & 17 & 24 & 6.9 & 22 & 71 \\
\hline 8 & adult & M & 0.50 & ND & 4.4 & 13 & 18 & 2.8 & 24 & 72 \\
\hline 9 & 12 & M & 1.56 & ND & 5.3 & 13 & 20 & 7.8 & 27 & 65 \\
\hline 10 & 8 & M & 2.67 & ND & 16 & 37 & 56 & 4.8 & 29 & 66 \\
\hline 11 & 35 & $\mathrm{~F}$ & 0.14 & ND & 1.8 & 3.1 & 5.0 & 2.8 & 36 & 62 \\
\hline 12 & 18 & M & 3.50 & ND & 11 & 32 & 47 & 7.5 & 23 & 68 \\
\hline 13 & 41 & M & 1.48 & $\mathrm{ND}$ & 5.6 & 11 & 18 & 8.2 & 31 & 61 \\
\hline 14 & 42 & M & 1.53 & 0.074 & 6.9 & 19 & 28 & 5.7 & 25 & 68 \\
\hline 15 & 63 & $\mathrm{~F}$ & 1.00 & 0.50 & 8.6 & 35 & 45 & 3.3 & 19 & 78 \\
\hline 16 & & M & 0.78 & 0.24 & 17 & 29 & 47 & 2.2 & 36 & 62 \\
\hline 17 & adult & M & 0.080 & ND & 2.7 & 4.2 & 7.0 & 1.1 & 39 & 60 \\
\hline 18 & 48 & $F$ & 0.48 & ND & 28 & 126 & 154 & 0.31 & 18 & 82 \\
\hline 19 & adult & $\mathrm{F}$ & 0.28 & 0.012 & 19 & 30 & 49 & 0.60 & 39 & 61 \\
\hline 20 & adult & $\mathrm{F}$ & 0.28 & 0.21 & 13 & 29 & 42 & 1.2 & 31 & 69 \\
\hline 21 & 44 & $\mathrm{~F}$ & 0.71 & ND & 33 & 143 & 177 & 0.40 & 19 & 81 \\
\hline 22 & 48 & $\mathrm{~F}$ & 2.7 & 1.8 & 120 & 600 & 725 & 0.62 & 17 & 83 \\
\hline 23 & 67 & M & 2.4 & ND & 105 & 240 & 348 & 0.68 & 30 & 69 \\
\hline 24 & 34 & $\mathrm{~F}$ & 3.0 & 0.21 & 150 & 530 & 683 & 0.47 & 22 & 78 \\
\hline
\end{tabular}

${ }^{*} \mathrm{NE}=$ norepinephrine, $\mathrm{E}=$ epinephrine, $\mathrm{NMN}=$ normetanephrine, $\mathrm{MN}=$ metanephrine, and $\mathrm{VMA}=$ vanilmandelic acid.

$\dagger$ All values corrected for expected normal excretion as described in Methods. These were 0.030 for NE, 0.006 for $\mathrm{E}$, 0.62 for $\mathrm{NMN}+\mathrm{MN}$, and 3.7 for VMA, per day.

$\ddagger N D=$ not detected, being less than $5 \%$ of value for $\mathrm{NE}$.

precluded a simple linear regression analysis of the series as a whole. To facilitate the comparison of certain variables, the series was divided arbitrarily into two groups, each representing one-half of the spectrum shown in Figures 1 and 2. One group, designated "low," consisted of the 13 patients who had a total tumor store of NE plus $E$ of less than $100 \mathrm{mg}$ (No. 1 to 13 , Table I). The "high" group was composed of the 9 patients whose total tumor content of $\mathrm{Ne}$ plus $\mathrm{E}$ ranged from $329 \mathrm{mg}$ to $10.6 \mathrm{~g}$ (No. 14 to 22). Six of the 7 patients in the series who excreted increased amounts of $\mathrm{E}$ as well as $\mathrm{NE}$ fell into the latter category. These two groups are compared in Table II. Tumors classified in the low group had a mean rate of turnover of catecholamines 8 times that of the tumors in the high group (68 versus $8.1 \%$ per day). The smaller total pool size of catecholamines in the low group was due to both a lower weight in grams and a lesser tissue concentration of NE plus E (milligrams per gram). Thus, the tumors of patients shown on the left-hand side of Figures 1 and 2 (low group) were characterized by a rapid rate of turnover, a low storage capacity for catecholamines, and a small size. Tumors in the high group, on the other hand, had a greater capacity to store $\mathrm{NE}$ and $\mathrm{E}$ and a large size; these properties were associated with a lesser percentage excretion of free catecholamines in the urine than was found in the low group.

Urinary values in pheochromocytoma versus those produced by an infusion of catecholamines. In Table III the mean urinary excretion values in these two groups are compared to those reported for patients given infusions of radioactive $\mathrm{NE}$ or $\mathrm{E}$. The ratio of urinary $\mathrm{NE}$ (or $\mathrm{E}$ or both) to VMA reflects the extent to which catecholamines were degraded in these different groups of patients. Whereas almost all persons with 
TABLE I

findings in 24 patients*

\begin{tabular}{|c|c|c|c|c|c|}
\hline \multirow[b]{2}{*}{ Location } & \multicolumn{3}{|c|}{ Data on tumors } & \multirow[b]{2}{*}{$\begin{array}{c}\text { Total NE } \\
+E\end{array}$} & \multirow[b]{2}{*}{$\begin{array}{c}\mathrm{NE}+\mathrm{E} \\
\text { released }\end{array}$} \\
\hline & $W_{t}$ & $\mathrm{NE}$ & $\mathrm{E}$ & & \\
\hline & $g$ & $m g / g$ & $m g / g$ & $m g$ & $\begin{array}{c}\% \text { of total } / \\
\text { day }\end{array}$ \\
\hline R. adrenal & 26 & 0.68 & 0.056 & 19 & 105 \\
\hline R. adrenal & 24 & 0.83 & ND & 20 & 220 \\
\hline Adrenal & 7.0 & 1.5 & 1.7 & 22 & 43 \\
\hline L. adrenal & 7.7 & 4.4 & ND & 34 & 74 \\
\hline Neck & 25 & 1.5 & ND & 38 & 55 \\
\hline R. adrenal & 124 & 0.34 & ND & 42 & 130 \\
\hline L. adrenal & 30 & 2.0 & ND & 60 & 40 \\
\hline R. adrenal & 17.5 & 3.0 & 0.63 & 64 & 28 \\
\hline L. adrenal & 8.0 & 8.3 & ND & 66 & 30 \\
\hline Neck & 15 & 5.0 & ND & 75 & 73 \\
\hline L. adrenal & 12 & 6.3 & ND & 76 & 6.6 \\
\hline Adrenal & 37 & 2.3 & ND & 85 & 54 \\
\hline R. adrenal & 46 & 1.9 & $\mathrm{ND}$ & 87 & 21 \\
\hline \multicolumn{6}{|l|}{ Organ of } \\
\hline Zuckerkandl & 37 & 8.4 & 0.5 & 329 & 8.5 \\
\hline $\mathrm{R}$. adrenal & 47 & 5.8 & 2.4 & 386 & 12 \\
\hline \multicolumn{6}{|l|}{ Organ of } \\
\hline Zuckerkandl & 95 & 4.0 & 1.2 & 494 & 9.5 \\
\hline L. adrenal & 42 & 11.2 & 0.6 & 495 & 1.4 \\
\hline L. adrenal & 165 & 3.7 & ND & 610 & 25 \\
\hline R. adrenal & 192 & 5.9 & 0.38 & 1,205 & 4.1 \\
\hline R. adrenal & 100 & 11.4 & 8.2 & 1,960 & 2.1 \\
\hline R. adrenal & 430 & 9.8 & 2.1 & 5,120 & 3.5 \\
\hline \multirow{3}{*}{$\begin{array}{l}\text { L. adrenal } \\
\left\{\begin{array}{l}\text { Metastatic to } \\
\text { peritoneum, } \\
\text { lungs, liver }\end{array}\right.\end{array}$} & 850 & 6.2 & 6.3 & 10,600 & 6.8 \\
\hline & & & & & \\
\hline & & 2.6 & 0.58 & & \\
\hline
\end{tabular}

pheochromocytoma appeared to metabolize $\mathrm{NE}$ and $\mathrm{E}$ more completely than might be predicted from the infusion data, those with a low tumor content of catecholamines had a NE plus E: VMA ratio closest to that produced by an infusion of these amines. If patients in the low group did receive relatively pure infusions of $\mathrm{NE}$ and $\mathrm{E}$ from their tumors, and if all persons metabolize circulating catecholamines in a quantitatively similar way, then one would expect a linear correlation between the excretion of total metabolites and the excretion of free catecholamines in the individual patients of the low group. Figure 3 shows such a correlation $(\mathrm{r}=0.90 ; \mathrm{p}<0.001)$. In contrast, patients with a high total content of NE plus $\mathrm{E}$ in their tumors showed no correlation between their excretions of total metabolites and of free catecholamines (Figure 3 ).

To explain the urinary pattern in patients with a high tumor content of $\mathrm{NE}$ plus $\mathrm{E}$, one must postulate either that these patients metabolize circulating $\mathrm{NE}$ and $\mathrm{E}$ more completely than do other persons or that in these patients some of the catecholamine was metabolized directly in the tumor before it entered the circulation. No studies were done to exclude directly the first possibility; however, a tenfold increase in the ability of the body to metabolize circulating $\mathrm{NE}$ would have to occur to account for the findings in Patients 18, 19, and 21 to 24 solely by this mechanism. To examine the possibility that the tumor metabolized as well as synthesized NE and E, 9 tumors were assayed for the O-methylated metabolites, NMN and MN. Figure 4 shows that the excretion of NE plus $\mathrm{E}$ relative to total metabolites decreased sharply as the concentration of $\mathrm{NMN}$ plus $\mathrm{MN}$ in the tumor increased, i.e., increased degradation of $\mathrm{NE}$ and $\mathrm{E}$ within the tumor was associated with a relative increase in metabolites in the urine. Pheochromocytomas have been shown $(9,10)$ to contain mono- 


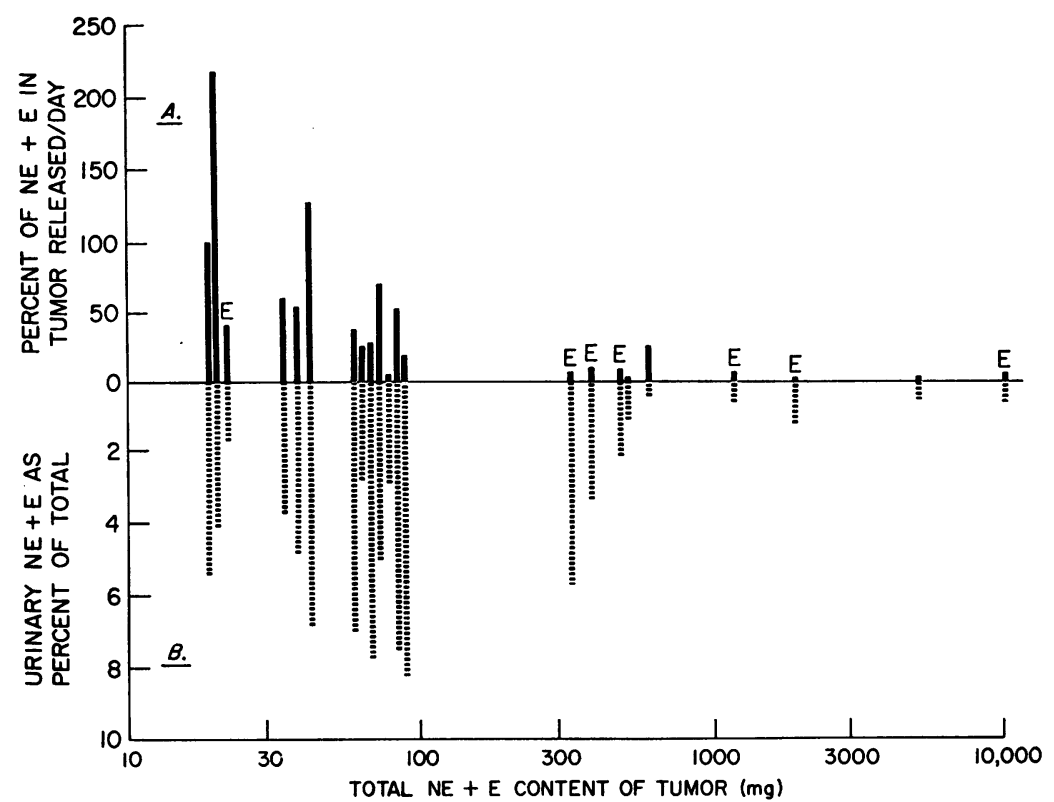

Fig. 2. Per cent of tumor store of NE plus E Released Per day (2A) AND PER CENT OF URINARY METABolites EXCRETEd AS NE PLuS E (2B) PLOTted AS Functions of the total CONTENT OF NE PLUS E IN THE TUMOR.

amine oxidase and catechol-O-methyl transferase, the two major enzymes involved in the metabolism of $\mathrm{NE}$ and $\mathrm{E}$; in addition, $\mathrm{NMN}, \mathrm{MN}$, and 3-methoxy-4-hydroxyphenylglycol have all been chemically identified in these tumors $(9,11)$. The quantitative significance of this in situ metabolism has not, however, been emphasized in previous studies. If we assume that the free $\mathrm{NE}$ plus $\mathrm{E}$ in the urine represents $5.1 \%$ of that actually secreted into the circulation as the free vasoactive amine (Table III, low group), it follows that in Patients 17 to 24 (Table I), 75 to $95 \%$ of the $\mathrm{NE}$ and $\mathrm{E}$ synthesized by the tumor was metabolized before its entry into the blood stream.

Malignant pheochromocytoma. Urinary excretion data from 2 patients with widespread metastatic pheochromocytoma are included in Table I (Cases 23 and 24). Both demonstrated a pattern of urinary catecholamine metabolites typical of patients with a high content of $\mathrm{NE}$ plus $\mathrm{E}$ in

TABLE II

Mean values in two groups of patients with pheochromocytoma

\begin{tabular}{|c|c|c|c|}
\hline & $\begin{array}{l}\text { "Low" NE+E con- } \\
\text { tent of tumor } \\
\text { (Case No. 1-13) }\end{array}$ & $\begin{array}{l}\text { "High" NE }+E \text { con- } \\
\text { tent of tumor } \\
\text { (Case No. 14-22) }\end{array}$ & $\mathrm{p}^{*}$ \\
\hline Urinary excretion & mean $\pm \mathrm{SE}$ & mean $\pm \mathrm{SE}$ & \\
\hline $\begin{array}{l}\text { Total metabolites, } m g / d a y \\
\text { VMA, mg/day } \\
\text { NMN } \pm \text { MN, mg/day } \\
\text { NE + E, } m g / d a y \\
\text { NE + E, as \% of total }\end{array}$ & $\begin{array}{l}28 \pm 4.7 \\
19 \pm 3.1 \\
7.0 \pm 1.3 \\
1.6 \pm 0.32 \\
5.1 \pm 0.59\end{array}$ & $\begin{array}{l}142 \pm 75 \\
113 \pm 63 \\
28 \pm 12 \\
1.2 \pm 0.63 \\
1.7 \pm 0.63\end{array}$ & $\begin{array}{l}0.04 \\
0.06 \\
0.02 \\
0.25 \\
0.002\end{array}$ \\
\hline \multicolumn{4}{|l|}{ Tumor } \\
\hline $\begin{array}{l}\mathrm{Wt}, g \\
\mathrm{NE}+\mathrm{E} \text { concentration, } m g / g \\
\text { Total NE + E content, } m g \\
\mathrm{NE}+\mathrm{E} \text { in tumor released, } \% / d a y\end{array}$ & $\begin{array}{l}29 \pm 8.6 \\
3.1 \pm 0.66 \\
53 \pm 6.9 \\
68 \pm 16\end{array}$ & $\begin{aligned} 218 & \pm 89 \\
9.8 & \pm 1.6 \\
2,355 & \pm 1150 \\
8.1 & +2.4\end{aligned}$ & $\begin{array}{l}0.001 \\
0.001 \\
0.001 \\
0.001\end{array}$ \\
\hline
\end{tabular}

${ }^{*} \mathrm{p}=$ probability that the two means are drawn from the same population, as measured by the Wilcoxon two-sample test (8). The large difference in variation between the two groups precludes the meaningful use of the $t$ test. 
TABLE III

Urinary excretion of catecholamines and their metabolites: comparison of values from radioactive tracer studies to values in pheochromocytoma

\begin{tabular}{|c|c|c|c|c|c|c|c|}
\hline \multirow[b]{2}{*}{ Compound infused } & \multirow{2}{*}{$\begin{array}{l}\text { No. of } \\
\text { patients }\end{array}$} & \multicolumn{5}{|c|}{$\begin{array}{l}\text { Urinary excretion as \% of the total radioactivity } \\
\text { recovered in } 24 \text { hours }\end{array}$} & \multirow[b]{2}{*}{ Reference } \\
\hline & & $\mathrm{NE}(\mathrm{E})$ & $\mathrm{NMN}(\mathrm{MN})$ & VMA & Other & $\mathrm{NE}(\mathrm{E}): \mathrm{VMA}$ & \\
\hline \multicolumn{8}{|l|}{ Normal } \\
\hline \multirow[t]{2}{*}{$\begin{array}{l}d, l-\mathrm{NE}\left(\mathrm{C}^{14}\right) \\
d, l-\mathrm{E}\left(\mathrm{C}^{14}\right) \\
d, l-\mathrm{E}\left(\mathrm{H}^{3}\right)\end{array}$} & $\begin{array}{l}6 \\
6 \\
6\end{array}$ & $\begin{array}{l}4 \\
4\end{array}$ & $\begin{array}{l}22 \\
47 \\
55\end{array}$ & $\begin{array}{l}32 \\
27 \\
35\end{array}$ & $\begin{array}{l}40 \\
22 \\
10\end{array}$ & $\begin{array}{l}1: 8 \\
1: 7\end{array}$ & $\begin{array}{l}(3) \\
(2) \\
(1)\end{array}$ \\
\hline & \multicolumn{7}{|c|}{$\begin{array}{c}\text { Urinary excretion as } \% \text { of total metabolites } \\
\text { (from Table I) }\end{array}$} \\
\hline \multicolumn{8}{|l|}{ Pheochromocytoma } \\
\hline $\begin{array}{l}l \text {-NE, "low" group } \\
l \text {-NE }+l \text {-E, "high" group }\end{array}$ & $\begin{array}{r}13 \\
9\end{array}$ & $\begin{array}{l}5.1 \\
1.7\end{array}$ & $\begin{array}{l}25 \\
27\end{array}$ & $\begin{array}{l}70 \\
71\end{array}$ & & $\begin{array}{l}1: 14 \\
1: 42\end{array}$ & \\
\hline
\end{tabular}

their tumors. Both of these patients had primary adrenal pheochromocytomas removed several years before the development of metastases, but no data are available to indicate what their patterns of urinary metabolites might have been at that time.

\section{Discussion}

Pheochromocytomas are known to vary widely in their size and their catecholamine content (9, $12,13)$. The data presented here confirm previous suggestions $(9,14)$ that the rate of turnover

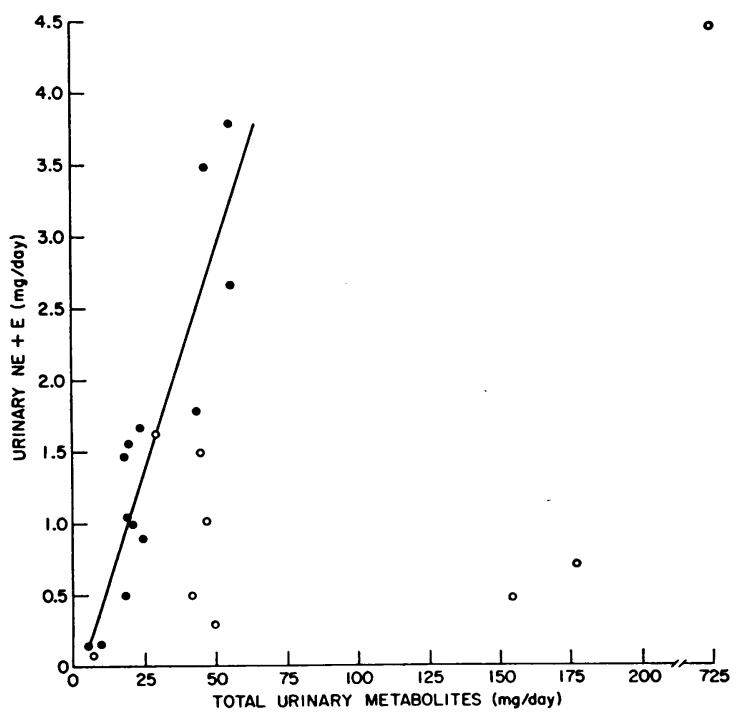

Fig. 3. URINARy excretion of NE plus E versus EXCRETION of total METABolites. Solid dots are Patients 1 to 13 ("low" total content of NE plus $\mathrm{E}$ in tumor) ; regression equation for this group is $\mathrm{y}=0.062 \times-0.18$. Open circles are Patients 14 to 22 ("high" content of $\mathrm{NE}$ plus $\mathrm{E}$ in tumor). of catecholamines also varies over a wide range, and reveal that metabolism of catecholamines in situ is yet another factor contributing to the biochemical individuality of each tumor. When these tumors are arranged into a spectrum on the basis of their total pool size of NE plus E, however, certain of these apparently random variables do clearly fall into a pattern. One end of the spectrum is represented by neoplasms with relatively small total stores of catecholamines. Since most of these tumors produce only NE, they presumably lack the cells that normally $n$-methylate $\mathrm{NE}$ to $\mathrm{E}(15,16)$. Also, most have a relatively low concentration of tissue $\mathrm{NE}$ and a high rate of turnover of catecholamines $(68 \pm 16 \%$ of the total store replaced each day). Patients harbor-

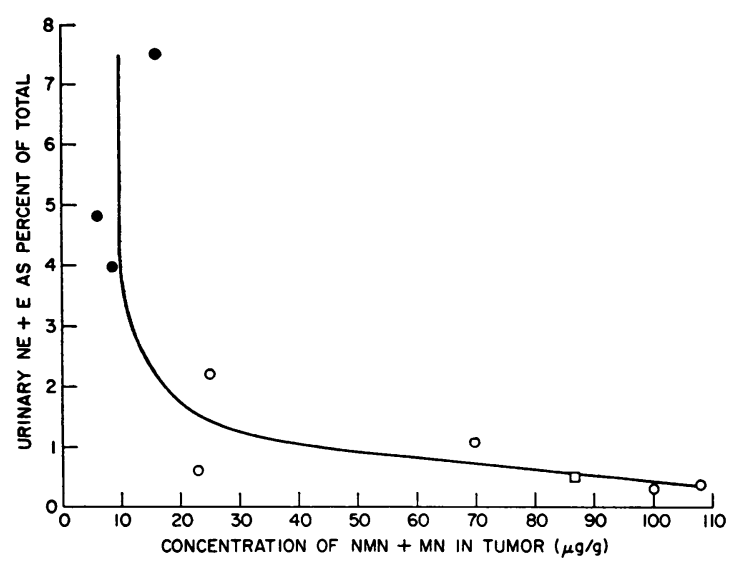

Fig. 4. Per cent of total metabolites exCreted as NE plus E plotted against the CONCENTRAtion of NMN plus MN IN THE TUMOR. Open square is Case 24 (metastatic pheochromocytoma); other symbols are the same as in Figure 3. 
ing such tumors may be subjected to high concentrations of circulating $\mathrm{NE}$ before the tumor has grown large.

Tumors at the other end of the spectrum tend to exhibit a high storage capacity for catecholamines and a low rate of turnover of their catecholamine store $(8.1 \pm 2.4 \%$ per day $)$. This rate of turnover is similar to that reported for the normal adrenal medulla of the rat (17) and the mouse (18). A substantial portion (up to 95\%) of the catecholamines synthesized by these tumors is apparently metabolized directly in the tumor and therefore does not enter the circulation as free $\mathrm{NE}$ or $\mathrm{E}$. The over-all result is that the rate of secretion of pharmacologically active NE and E per gram of tumor is low; thus symptoms sufficient to bring the patient to the attention of a physician may not develop until the tumor has grown to considerable size.

This arbitrary separation of patients into two distinct groups does not imply that all patients can be neatly classified or that exceptions to this idealized spectrum do not occur. The literature records, for example, a number of cases in which a small tumor has produced $\mathrm{E}$ as well as $\mathrm{NE}$ (13; also Case No. 3, Table I). The release of catecholamines from these tumors may be highly erratic in certain clinical situations; thus, a hypertensive attack may be accompanied by a substantial increase in both the rate of excretion of catecholamines $(13,19)$ and the ratio of urinary NE to VMA $(19,20)$.

In the normal adrenal medulla, almost all of the catecholamines are held in small intracellular granules in combination with adenosine triphosphate and protein $(21,22)$. In the pheochromocytoma cell, however, this is apparently not the case. In studying a tumor with a high content of NE plus E, Hillarp, Lindqvist, and Vendsalu (23) found the molar ratio of catecholamines to adenine nucleotides to be many times higher than the $4: 1$ ratio expected for normal adrenals. In a tumor that would have been included in the low group in this paper, Gélinas, Pellerin, and D'Iorio (24) also found an unusually low concentration of adenosine triphosphate; in addition, they noted that only $30 \%$ of the catecholamines were bound to the granular fraction. A similar subcellular distribution of catecholamines-i.e., most being free in the supernatant fraction rather than bound to the sedimented granules-was reported for two pheochromocytomas (one $10 \mathrm{~g}$ and the other $600 \mathrm{~g}$ ) by Burger and Langemann (10). One of these tumors contained a remarkable quantity of zinc ( 0.21 to $0.51 \mathrm{mg}$ per $\mathrm{g}$ ), which led Langemann (25) to postulate that in certain tumors catecholamines might be stored in combination with this metal. These observations all suggest that the binding of catecholamines in pheochromocytomas is qualitatively different from normal and that the intracellular concentration of unbound amine is high. Hillarp and associates (23) have proposed that a continuous "overflow" of catecholamines from this free cytoplasmic pool is the cause of the autonomous secretory activity of these tumors; continued synthesis of new amine in the face of an overflowing store is attributed by these authors to a defect in the feedback regulation of synthesis rate. A high concentration of unbound intracellular norepinephrine might also explain the picture found in tumors at the high NE plus E content end of the spectrum. Since monoamine oxidase and catechol-O-methyl transferase are also present within the cell, metabolism of unbound amine by these enzymes would reduce the overflow of free vasoactive norepinephrine but increase the overflow of metabolites. This concept would imply that those tumors that do not metabolize large amounts of their free cytoplasmic catecholamines have a relative deficiency of monoamine oxidase and catechol-Omethyl transferase, although no data are available to confirm or deny this hypothesis.

Some implications of these data in diagnosis might be noted. Although most patients with pheochromocytoma exhibit a diagnostic increase in their urinary excretion of free catecholamines and all metabolites, occasional patients have an increase in free catecholamine excretion in the presence of a normal excretion of VMA (5), whereas others are reported to show an increase in VMA excretion in the presence of normal or near normal values for free urinary $\mathrm{NE}$ and $\mathrm{E}$ $(19,26)$. It is important to recognize that both situations may occur and that the diagnostic value of a given assay (e.g., free catecholamines versus VMA excretion), particularly in a patient with a minimal increase in total catecholamine production, may depend upon the degree of in situ metabolism and upon the secretion rate of the tumor 
at the time of the urine collection. For example, if a considerable portion of the catecholamine synthesized is degraded directly in the tumor and if free $\mathrm{NE}$ and $\mathrm{E}$ tend to be released from the tumor only during paroxysmal attacks, the excretion of VMA may be proportionately greater (relative to normal) than the free catecholamine excretion under resting conditions, but the excretion of free catecholamines may increase relatively more than the VMA excretion during a paroxysmal discharge of $\mathrm{NE}$ and $\mathrm{E}$ from the tumor. The case of Kraupp, Stormann, and Bernheimer (19) is a well-documented example of this situation. In children with neuroblastoma, ratios of urinary NE to VMA are extremely variable and frequently very low (27), suggesting that extensive metabolism of NE occurs in these tumors as well as in pheochromocytoma; in the case of neuroblastoma, the VMA excretion is usually the more valuable diagnostic aid (28).

Total catecholamine production in 5 of these patients was greater than $150 \mathrm{mg}$ per day and in one (Patient 22) reached the remarkable value of $725 \mathrm{mg}$ per day; the total quantity of NE plus $\mathrm{E}$ in this tumor was estimated to be $10.6 \mathrm{~g}$. The synthesis of $725 \mathrm{mg}$ per day of catecholamines requires only about $20 \%$ of the estimated tyrosine intake of the average American (3.6 g per day) or $9 \%$ of the combined phenylalanine plus tyrosine intake ( $8.2 \mathrm{~g}$ per day) (29). Therefore, in most pheochromocytomas the catecholamine pathway does not utilize a large fraction of the dietary intake of these aromatic amino acids. This situation may be contrasted with that in malignant carcinoid, where up to $60 \%$ of the dietary tryptophan may be diverted into the production of 5-hydroxytryptamine with resultant impairment of niacin and protein synthesis (30).

\section{Summary}

The 24-hour urinary excretions of free norepinephrine (NE) and epinephrine (E), of total normetanephrine plus metanephrine (NMN plus $\mathrm{MN}$ ), and of 3-methoxy-4-hydroxymandelic acid (VMA) were measured in 24 patients with pheochromocytoma. In addition, 23 tumors were assayed for NE and E, and 9 for NMN plus MN.

The results demonstrate that individual tumors vary widely in their rates of production and turn- over of catecholamines. In some the catecholamine store is replaced at a rapid rate, and a relatively pure infusion of $\mathrm{NE}$ (and sometimes $\mathrm{E}$ ) is secreted into the host; these tumors are usually small in size (less than $50 \mathrm{~g}$ ). In other tumors the catecholamine store is turned over more slowly, and a considerable portion of the NE and $\mathrm{E}$ synthesized is apparently metabolized directly in the tumor; these neoplasms are usually large (over $50 \mathrm{~g}$ ). We postulate that tumors of the latter type escape detection until they become large because their rate of secretion of pharmacologically active NE and E per gram of tumor is low. There is no sharp borderline between these two types of tumors, and the series as a whole should be viewed as a spectrum rather than as a population containing distinct subgroups.

The concept is presented that the intracellular binding of catecholamines, the regulation of catecholamine synthesis, and the activity of catecholamine-degrading enzymes may all be abnormal in the pheochromocytoma cell. Varying degrees of imbalance between these processes could account for the autonomous secretion of $\mathrm{NE}$ and $\mathrm{E}$ by these tumors and for their wide variation in rates of production and release of free catecholamines.

\section{Acknowledgments}

We are grateful to Miss Doris Watts and to Mrs. Consuelo Muellenberg for their expert technical assistance.

\section{References}

1. LaBrosse, E. H., J. Axelrod, and S. Kety. O-methylation, the principal route of metabolism of epinephrine in man. Science 1958, 128, 593.

2. Kirshner, N., McC. Goodall, and L. Rosen. Metabolism of $\mathrm{dl}_{\text {-adrenaline-2- }} \mathrm{C}^{\mathbf{4}}$ in the human. Proc. Soc. exp. Biol. (N. Y.) 1958, 98, 627.

3. Goodall, McC., N. Kirshner, and L. Rosen. Metabolism of noradrenaline in the human. J. clin. Invest. 1959, 38, 707.

4. Von Euler, U. S. Noradrenaline. Springfield, Ill. Charles C Thomas, 1956, p. 56.

5. Crout, J. R., J. J. Pisano, and A. Sjoerdsma. Urinary excretion of catecholamines and their metabolites in pheochromocytoma. Amer. Heart J. 1961, 61,375 .

6. Crout, J. R. Catecholamines in urine in Standard Methods of Clinical Chemistry, D. Seligson, Ed. New York, Academic Press, 1961, vol. 3, pp. 62-80.

7. Pisano, J. J., J. R. Crout, and D. Abraham. The determination of 3-methoxy-4-hydroxymandelic acid in urine. Clin. chim. Acta. 1962, 7, 285. 
8. Wallis, W. A., and H. V. Roberts. Statistics, A New Approach. Glencoe, Ill., Free Press, 1956, p. 594.

9. Sjoerdsma, A., L. C. Leeper, L. L. Terry, and S. Udenfriend. Studies on the biogenesis and metabolism of norepinephrine in patients with pheochromocytoma. J. clin. Invest. 1959, 38, 31.

10. Burger, M., and H. Langemann. Bestimmungen von Adrenalin und Noradrenalin sowie von Decarboxylase- und Aminoxydase-Aktivitäten in Zellfraktionen von Phäochromocytomen. Klin. Wschr. 1956, 34, 941.

11. Kopin, I. J., and J. Axelrod. Presence of 3-methoxy4-hydroxyphenyl-glycol and metanephrine in phæochromocytoma tissue. Nature (Lond.) 1960, 185, 788 .

12. Goodall, McC., and C. Stone. Adrenaline and noradrenaline producing tumors of the adrenal medulla and sympathetic nerves. Ann. Surg. 1960, 151, 391.

13. Von Euler, U. S., and G. Ström. Present status of diagnosis and treatment of pheochromocytoma. Circulation 1957, 15, 5.

14. Von Euler, U. S. Adrenal medullary and other chromaffine tumours in Ciba Foundation Colloquia on Endocrinology. Boston, Little, Brown, 1958, vol. 12.

15. Hillarp, N. Å., and B. Hokfelt. Evidence of adrenaline and noradrenaline in separate adrenal medullary cells. Acta physiol. scand. 1953, 30, 55.

16. Eränkö, O. Distribution of adrenaline and noradrenaline in the adrenal medulla. Nature (Lond.) $1955,175,88$.

17. Udenfriend, S., J. R. Cooper, C. I. Clark, and J. E. Baer. Rate of turnover of epinephrine in the adrenal medulla. Science 1953, 117, 663.

18. Burack, W. R., and P. R. Draskóczy. Personal communication.

19. Kraupp, O., H. Stormann, H. Bernheimer, and H. Obenaus. Vorkommen und diagnostische Bedeutung von Phenolsäuren in Harn beim Phäochromocytom. Klin. Wschr. 1959, 37, 76.
20. Hamrin, B. Sustained hypotension and shock due to an adrenaline-secreting phaeochromocytoma. Lancet 1962, 2, 123.

21. Hillarp, N-Å., B. Högberg, B. Nilson, and A. B. Leo. Adenosine triphosphate in the adrenal medulla of the cow. Nature (Lond.) 1955, 176, 1032.

22. Blaschko, H., G. V. R. Born, A. D'Iorio, and N. R. Eade. Observations on the distribution of catechol amines and adenosinetriphosphate in the bovine adrenal medulla. J. Physiol. 1956, 133, 548.

23. Hillarp, N. A., M. Lindqvist, and A. Vendsalu. Catechol amines and nucleotides in pheochromocytoma. Exp. Cell Res. 1961, 22, 40.

24. Gélinas, R., J. Pellerin, and A. D'Iorio. Biochemical observations of a chromaffine tumour. Rev. Canad. Biol. 1957, 16, 445.

25. Langemann, $H$. Bestimmungen von Fermenten und ihren Subtraten und Reaktionsprodukten in Zellfraktionen von Dünndarmkarzinoid-metastate und Phaeochromozytom. Acta neuroveg. (Wien) 1957, 16, 333.

26. Gitlow, S. E., M. Mendlowitz, S. Khassis, G. Cohen, and J. Sha. The diagnosis of pheochromocytoma by determination of urinary 3-methoxy, 4-hydroxymandelic acid. J. clin. Invest. 1960, 39, 221.

27. Voorhess, M. L., and L. I. Gardner. Urinary excretion of norepinephrine, epinephrine and 3methoxy-4-hydroxymandelic acid by children with neuroblastoma. J. clin. Endocr. 1961, 21, 321.

28. Von Studnitz, W., H. Käser, and A. Sjoerdsma. The spectrum of catecholamine biochemistry in patients with neuroblastoma. New Engl. J. Med. 1963, 269, 232.

29. Evaluation of Protein Nutrition. Report of the Food and Nutrition Board, Nat. Acad. of Sci., Nat. Res. Council Publication 711. Washington, D. C., 1959.

30. Sjoerdsma, A., H. Weissbach, and S. Udenfriend. A clinical, physiologic, and biochemical study of patients with malignant carcinoid (argentaffinoma). Amer. J. Med. 1956, 20, 520. 